\title{
Effects of ruminally degradable starch levels on performance, nitrogen balance, and nutrient digestibility in dairy cows fed low corn-based starch diets
}

\author{
Guobin Luo ${ }^{1}$, Wenbin $\mathrm{Xu}^{1}$, Jinshan Yang ${ }^{1}$, Yang Li ${ }^{1}$, Liyang Zhang ${ }^{1}$, Yizhen Wang ${ }^{1}$, \\ Cong Lin ${ }^{1}$, and Yonggen Zhang ${ }^{1, *}$
}

\begin{abstract}
* Corresponding Author: Yonggen Zhang Tel: +86-451-55190840, Fax: +86-451-55190840, E-mail: zhangyonggen@sina.com
\end{abstract}

'College of Animal Science and Technology, Northeast Agricultural University, Harbin 150030, China

Submitted May 10, 2016; Revised Jul 20, 2016; Accepted Sept 18, 2016
Objective: This trial was performed to examine the effects of ruminally degradable starch (RDS) levels in total mixed ration (TMR) with low corn-based starch on the milk production, whole-tract nutrient digestibility and nitrogen balance in dairy cows.

Methods: Eight multiparous Holstein cows (body weight [BW]: $717 \pm 63 \mathrm{~kg}$; days in milk [DIM]: 169 \pm 29 ) were assigned to a crossover design with two dietary treatments: a diet containing $62.3 \%$ ruminally degradable starch (\% of total starch, low RDS) or $72.1 \%$ ruminally degradable starch (\% of total starch, high RDS). Changes to the ruminally degradable levels were conducted by using either finely ground corn or steam-flaked corn as the starch component.

Results: The results showed that dry matter intake, milk yield and composition in dairy cows were not affected by dietary treatments. The concentration of milk urea nitrogen was lower for cows fed high RDS TMR than low RDS TMR. The whole-tract apparent digestibility of neutral detergent fiber, acid detergent fiber and crude protein decreased, and that of starch increased for cows fed high RDS TMR over those fed low RDS TMR, with no dietary effect on the whole-tract apparent digestibility of dry matter and organic matter. The proportion of urinary $\mathrm{N}$ excretion in $\mathrm{N}$ intake was lower and that of fecal $\mathrm{N}$ excretion in $\mathrm{N}$ intake was higher for cows fed high RDS TMR than those fed low RDS TMR. The $\mathrm{N}$ secretion in milk and the retention of $\mathrm{N}$ were not influenced by the dietary treatments. Total purine derivative was similar in cows fed high RDS TMR and low RDS TMR. Consequently, estimated microbial $\mathrm{N}$ flow to the duodenum was similar in cows fed high RDS TMR and low RDS TMR.

Conclusion: Results of this study show that ruminally degradable starch levels can influence whole-tract nutrient digestibility and nitrogen balance in dairy cows fed low corn-based starch diets, with no influence on performance.

Keywords: Dairy Cow; Ruminally Degradable Starch; Milk Production, Nitrogen Balance; Nutrient Digestibility

\section{INTRODUCTION}

Starch is an important source of energy in the diets of dairy cows. It serves as a precursor of propionate from starch fermentation, and as a source of glucose absorbed directly in small intestine. Cereal grains are commonly used in the diets of dairy cows for supplying starch. However, it is forecasted that cereal prices will rise in the next years as a result of the increased demand from developing countries and the growing market for bio-fuels [1]. There is no doubt that the profitability of dairy farms will be affected immediately by the increases of cereal price. For these reasons, low starch diet rises the interests of milk producers.

Some reports have indicated that more degradable starch improved ruminal microbial protein synthesis $[2,3]$. Increase of ruminally degradable starch improves the proportion of urea recy- 
cled to the gastrointestinal tract by enhancing microbial utilization of ruminal $\mathrm{NH}_{3}$ [4]. On the other hand, starch digestion in the rumen influences accumulation of volatile fatty acids and total acids, $\mathrm{pH}$, microbial ecology, and has negative impacts on fibre digestion [5-7].

However, there are limited data for evaluating the effect of ruminally degradable starch levels in dairy cows fed diets with low starch. This study changes the dietary ruminally degradable levels by using either finely ground corn (FGC) or steam-flaked corn (SFC) as components of the cow diets. The objective is to determine the effect of dietary ruminally degradable starch levels on performance, nitrogen balance and nutrient digestibility in dairy cows fed diets with a low starch.

\section{MATERIALS AND METHODS}

All animal studies were conducted according to the animal care and use guidelines of the Animal Care and Use Committee of Animal Science and Technology College, Northeast Agricultural University.

\section{Cows, experimental design and diets}

Eight multiparous Holstein cows (Parity: $3 \pm 0.8$; body weight [BW]: $717 \pm 63 \mathrm{~kg}$; days in milk [DIM]: $169 \pm 29)$ were used in a crossover design with two dietary treatments (dietary ruminally degradable starch levels: $62.3 \%$ for low ruminally degradable starch level [low RDS], $72.1 \%$ for high ruminally degradable starch [high RDS]); The experimental period was $21 \mathrm{~d}$, with $14 \mathrm{~d}$ for treatment adaptation and $7 \mathrm{~d}$ for data collection. The dietary treatments were a diet containing $21 \%$ FGC, $21 \%$ SFC. The ingredient composition and chemical composition of the experimental diets is shown in Table 1. The SFC used in this study was manufactured commercially in the same process and batch (Tianzhengdingtai Feed Corp., Heilongjiang Province, China). Corn was steamed under same conditions $\left(100^{\circ} \mathrm{C}\right.$ for $\left.60 \mathrm{~min}\right)$ and flaked (STEAM CHMBR; Roskamp Chapion Company, Waterloo, IA, USA). Moisture in the chamber was raised to $18 \%$ to $19 \%$. The corn was then passed through a prewarmed roller mill $(50 \times 75 \mathrm{~cm})$ to produce a flake of $360 \mathrm{~g} / \mathrm{L}$ of density. All FGC was prepared in the same batch with an average geometric mean particle size of $1,030 \mu \mathrm{m}$. All experimental diets were formulated to meet or exceed the Chinese Feeding Standard for Dairy Cattle (Ministry of Agriculture of P. R. China, 2004) [8]. Throughout the experiment, cows were fed individually 2 times daily at $05: 30 \mathrm{~h}$ and 17:30 $\mathrm{h}$ in individual tie-stalls and had free access to fresh water. Diets were fed ad libitum to allow for at least $5 \%$ to $10 \%$ orts. Cows were milked 2 times daily at 09:00 $\mathrm{h}$ and 21:00 $\mathrm{h}$.

\section{Data and sample collection}

The amounts of feed offered and orts were weighed and representative samples were collected daily during the final $3 \mathrm{~d}$ of
Table 1. Ingredients and calculated chemical compositions of experimental total mixed ration

\begin{tabular}{|c|c|c|}
\hline Item & Low RDS ${ }^{1)}$ & High RDS \\
\hline \multicolumn{3}{|l|}{ Ingredients, $\%$ of DM } \\
\hline Corn silage & 18.4 & 18.4 \\
\hline Alfalfa hay & 9.2 & 9.2 \\
\hline Chinese wild rye grass & 7.4 & 7.4 \\
\hline Whole cottonseed & 8.3 & 8.3 \\
\hline Wet Brewers grains & 5.2 & 5.2 \\
\hline Beet pulp & 4.1 & 4.1 \\
\hline Steam-flaked corn & 0 & 20.5 \\
\hline Finely ground corn & 20.5 & 0 \\
\hline Soybean meal & 9.5 & 9.5 \\
\hline DDGS & 8.2 & 8.2 \\
\hline Wheat bran & 4.4 & 4.4 \\
\hline Soybean hull & 2.1 & 2.1 \\
\hline Premix ${ }^{2)}$ & 2.3 & 2.3 \\
\hline Sodium bicarbonate & 0.5 & 0.5 \\
\hline \multicolumn{3}{|l|}{ Chemical composition ${ }^{3)}$} \\
\hline DM (\%) & 56.7 & 56.6 \\
\hline Organic matter (\% of DM) & 92.4 & 92.4 \\
\hline Crude protein (\% of DM) & 17.8 & 17.7 \\
\hline Ether extract (\% of DM) & 4.0 & 3.8 \\
\hline Neutral detergent fiber (\% of DM) & 34.6 & 34.6 \\
\hline Acid detergent fiber ( $\%$ of DM) & 19.8 & 19.8 \\
\hline Starch (\% of DM) & 21.4 & 22.6 \\
\hline $\mathrm{NE}_{L}^{4)}(\mathrm{Mcal} / \mathrm{kg} \mathrm{DM})$ & 1.66 & 1.68 \\
\hline Rumen degradation ${ }^{5}$ ( $\%$ of total) starch & 62.3 & 72.1 \\
\hline \multicolumn{3}{|c|}{$\begin{array}{l}\text { DM, dry matter; DDGS, dstillers dried grains with solubles; } \mathrm{NE}_{1} \text {, net energy for lactation. } \\
\text { 1) RDS, ruminally degradable starch of } 62.3 \% \text { and } 72.1 \% \text { for the low and high RDS } \\
\text { treatments, respectively, as determined by in situ incubations. } \\
\text { 2) Premix contained (//g; DM basis): } 400,000 \mathrm{IU} \text { of vitamin A, } 40,000 \mathrm{IU} \text { of vitamin } \mathrm{D} \text {, } \\
600 \mathrm{IU} \text { of vitamin } \mathrm{E}, 16 \% \mathrm{Ca}, 3.3 \% \mathrm{P}, 11.8 \% \mathrm{Na}, 2.9 \% \mathrm{Mg}, 2,600 \mathrm{mg} \mathrm{Zn}, 2,400 \mathrm{mg} \\
\mathrm{Mn}, 550 \mathrm{mg} \mathrm{Cu}, 12 \mathrm{mg} \mathrm{Se}, 25 \mathrm{mg} \mathrm{I} \text {. } \\
\text { 3) } \\
{ }^{4)} \text { Calculated based on analyzed chemical composition of ingredients. } \\
\text { Calculated based on Feeding Standards of Dairy Cattle (Ministry of Agriculture of P. R. } \\
\text { 5ina recommendations, 2004). }\end{array}$} \\
\hline
\end{tabular}

each period. The orts samples were pooled and one sample was retained per cow per period. The samples of orts and total mixed ration (TMR) were dried at $65^{\circ} \mathrm{C}$ in an oven for $48 \mathrm{~h}$, then ground through a 1-mm mesh screen using a Wiley mill (Arthur $\mathrm{H}$. Thomas Co., Philadelphia, PA, USA) and stored until analysis. Fecal samples (approximately $200 \mathrm{~g}$, fresh basis) were taken daily from the rectum of each cow every $6 \mathrm{~h}$ on the days 19,20, and 21 of each experimental period, and samples from each time point were divided into 2 portions and samples were pooled across sampling times for each cow. Ten percent volume of $6 \mathrm{M}$ hydrochloric acid was added to one pooled portion from each cow immediately after sampling for subsequent nitrogen analysis. All fecal samples were dried at $60^{\circ} \mathrm{C}$ for at least $72 \mathrm{~h}$ in a forcedair oven, and ground to pass through a 1-mm screen for analysis later. Apparent total-tract nutrient digestibility was calculated using indigestible neutral detergent fiber (iNDF) as an internal marker, and $\mathrm{N}$ excretion in feces was calculated from $\mathrm{N}$ digestibility and N intake. Spot urine samples (each about $200 \mathrm{~g}$ ) were 
collected every $6 \mathrm{~h}$ on the days 19, 20, and 21 of each experimental period, Urine samples from each cow were pooled and a $10 \mathrm{~mL}$ of each subsample was acidified with $40 \mathrm{~mL}$ of 0.036 mol of $\mathrm{H}_{2} \mathrm{SO}_{4} / \mathrm{L}$ and immediately stored at $-20^{\circ} \mathrm{C}$ for subsequent analysis. The milk yield was measured daily and averaged on the days 15, 16, and 17 of each experimental period, and duplicate milk samples were taken at every milking. One set of duplicate samples was used for analysis of fat, protein, lactose and milk urea nitrogen (MUN) by infrared spectroscopy (MilkoScan FT6000, Foss Electric A/S, Hillerød, Denmark).

Dietary contents of RDS in the TMR were determined using the in situ incubation technique [9] with three ruminally cannulated Holstein cows (BW: $678 \pm 26.5 \mathrm{~kg}$; milk yield: $20.6 \pm 2.5 \mathrm{~kg}$; DIM: 276 \pm 19 ). The animals were housed in individual tie-stalls in the Livestock Research Building (Northeast Agricultural University) and were fed the basal diet (corn silage 28.9\%, Chinese wild rye grass $24.2 \%$ and concentrate $46.9 \%$ dry matter [DM] basis) at $2.8 \%$ of BW (DM basis) at 05:30 h and 17:30 h daily. Briefly, samples of each diet were ground through a 3-mm screen (Arthur H. Thomas Co., USA). Approximately $5 \mathrm{~g}$ sample was weighted into number-coded nylon bags $(10 \times 20 \mathrm{~cm} ; 50 \mu \mathrm{m}$ pore size; Ankom Technology Corp., Macedon, NY, USA). Incubations were carried out for 72, 48, 24, 12, 8, 4, 2, and 0 h. Procedures for ruminal incubation and post-incubation processing of bags were as described by Yu et al [9]. The samples were dried in an oven at $65^{\circ} \mathrm{C}$ for $48 \mathrm{~h}$ and were ground to pass through a 1-mm screen in a Cyclotec mill (Tecator 1093; Tecator AB, Hoganas, Sweden) for starch analysis.

\section{Chemical analysis}

The DM content of the feed, orts and fecal samples was examined by drying the sample at $105^{\circ} \mathrm{C}$ for $24 \mathrm{~h} . \mathrm{DM}$, ash, crude protein (CP) and the ether extrate were determined by AOAC methods [10]. The neutral detergent fiber (NDF) and acid detergent fiber (ADF) were determined according to the methods of Van Soest et al [11]. The starch was analyzed using a total starch assay kit (Megazyme International Ireland Ltd, Wicklow, Ireland). The samples from in situ incubations were analyzed for DM and starch as previously described. The urine samples were analyzed for Kjeldahl $\mathrm{N}$ as previously described for the feeds. The urine samples were analyzed for allantoin using the procedure described in Chen and Gomes [12] and uric acid using a Uric Acid assay Kit (Jiancheng Regent Corp, Nanjing, China), and creatinine content was calculated using a colorimetric picric acid assay. Creatinine is an established marker for determining urine volume and was assumed to be excreted at a rate of $29 \mathrm{mg} / \mathrm{kg}$ of BW for calculating the urine volume excretion [13]. The microbial $\mathrm{N}$ supply to the small intestine was calculated from urinary purine derivative (PD) excretion as described in Chen and Gomes [12].

\section{Statistical analyses}

Rumen degradation characteristics of starch were analyzed using the non-linear regression procedure of SAS (Version 9.2; SAS Institute, Inc. Cary, NC, USA)[14] using least squares regression (Gauss-Newton method) as described by Yu et al [9]. All other data were analyzed using the MIXED procedure of SAS (Version 9.2; SAS Institute, Inc., USA). Data were analyzed as a crossover design, the following model was used: $Y_{i j k}=\mu+P_{i}+C_{j}+T_{k}+\varepsilon_{i j k}$, where $Y_{i j k}$ is the dependent variable, $\mu$ is the overall mean, $P_{i}$ is the fixed effect of period $i, C_{j}$ is the random effect of cow $j, T_{k}$ is the fixed effect of treatment $\mathrm{k}$, and $\varepsilon_{\mathrm{ijk}}$ is the random residual error. Treatment differences were considered significant when $\mathrm{p} \leq 0.05$ and tendencies were discussed when $0.05<\mathrm{p} \leq 0.10$.

\section{RESULTS}

\section{Dietary characteristics}

Dietary ingredients and chemical composition are listed in Table 1. The contents of DM, CP, NDF, ADF and starch were similar between the dietary treatments. In situ ruminal incubation of TMR showed that dietary RDS levels were 62.3 and 72.1 of total starch for the low and high RDS treatments, respectively (Table 2).

\section{Dry matter intake and milk production}

Dry matter intake (DMI) was not affected by dietary treatments (Table 3). Neither milk yield nor energy-corrected milk (ECM) was affected by dietary treatments. Protein yield, fat yield, and lactose yield were also not affected by dietary treatments. There was no difference in compositions of protein, fat, lactose, and total solids between the dietary treatments. The concentration of MUN in cows fed high RDS TMR was lower than that in cows fed low RDS TMR $(p=0.03)$. The dietary treatments did not affect the ECM/DMI.

\section{Nutrient digestibility and nitrogen balance}

There was no difference in digestibility of DM between the dietary

Table 2. Starch degradation constants in total mixed rations

\begin{tabular}{|c|c|c|c|c|}
\hline Starch degradation & Low RDS ${ }^{1)}$ & High RDS & SEM & $p$-value \\
\hline$S^{2)}(\%)$ & 5.9 & 2.6 & 0.58 & 0.06 \\
\hline$D^{3)}(\%)$ & 91.3 & 96.2 & 0.98 & 0.07 \\
\hline$U^{4)}(\%)$ & 2.8 & 1.2 & 0.85 & 0.31 \\
\hline $\mathrm{Kd}^{5)}(\% / \mathrm{h})$ & 9.7 & 15.5 & 0.15 & $<0.001$ \\
\hline$\% \mathrm{BS}^{6)}(\%$ RUS) & 37.7 & 27.9 & 0.50 & $<0.001$ \\
\hline$\% \operatorname{EDS}^{71}(\%$ RDS) & 62.3 & 72.1 & 0.50 & $<0.001$ \\
\hline \multicolumn{5}{|c|}{ 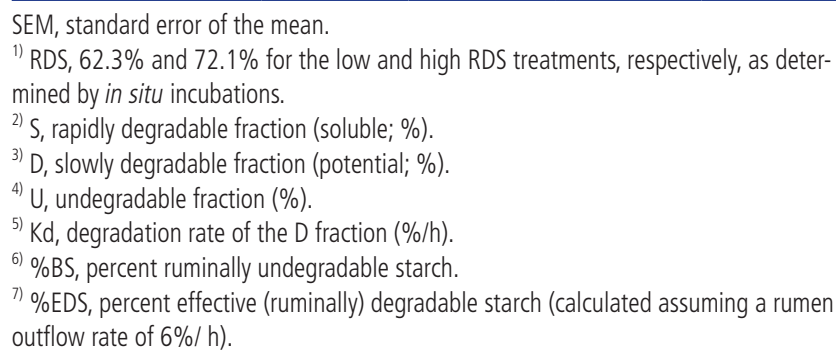 } \\
\hline
\end{tabular}


Table 3. Effects of dietary ruminally degradable starch levels on dry matter intake and lactation performance of dairy cows

\begin{tabular}{lcccc}
\hline Item & Low RDS $^{\text {1) }}$ & High RDS & SEM & p-value \\
\hline $\begin{array}{l}\text { DMI (kg/d) } \\
\text { Production }\end{array}$ & 22.6 & 21.9 & 0.50 & 0.20 \\
$\quad$ & & & \\
$\quad$ Milk yield (kg/d) & 27.8 & 27.2 & 0.58 & 0.32 \\
ECM $^{2)}(\mathrm{kg} / \mathrm{d})$ & 30.0 & 29.0 & 0.59 & 0.24 \\
$\quad$ Protein yield (kg/d) & 0.91 & 0.87 & 0.02 & 0.11 \\
$\quad$ Fat yield (kg/d) & 1.11 & 1.07 & 0.03 & 0.43 \\
$\quad$ Lactose yield (kg/d) & 1.38 & 1.40 & 0.03 & 0.67 \\
Composition & & & & \\
$\quad$ Protein (\%) & 3.26 & 3.18 & 0.08 & 0.43 \\
$\quad$ Fat (\%) & 4.00 & 3.94 & 0.1 & 0.64 \\
Lactose (\%) & 5.02 & 5.00 & 0.08 & 0.72 \\
Total solids (\%) & 13.74 & 13.48 & 0.22 & 0.21 \\
$\quad$ MUN (mg/dL) & 12.31 & 10.82 & 0.57 & 0.03 \\
Efficiency & & & & \\
$\quad$ ECM/DMl & 1.33 & 1.33 & 0.03 & 0.85 \\
\hline
\end{tabular}

SEM, standard error of the mean; ECM, energy-corrected milk; DMI, Dry matter intake; MUN, milk urea nitrogen.

1) RDS, ruminally degradable starch $62.3 \%$ and $72.1 \%$ for the low and high RDS treatments, respectively, as determined by in situ incubations.

${ }^{2)} E C M(\mathrm{~kg} / \mathrm{d})=0.327 \times$ milk $(\mathrm{kg} / \mathrm{d})+12.95 \times$ fat $(\mathrm{kg} / \mathrm{d})+7.65 \times$ protein $(\mathrm{kg} / \mathrm{d})$.

treatments (Table 4). The digestibility of OM in cows fed low RDS TMR tended to be higher $(p=0.09)$ than that in cows fed high RDS TMR. However, significant differences in digestibility of $\mathrm{CP}(\mathrm{p}=0.01), \mathrm{NDF}(\mathrm{p}=0.04), \mathrm{ADF}(\mathrm{p}=0.04)$, and starch $(\mathrm{p}=0.05)$ were observed. The digestibility of $\mathrm{CP}, \mathrm{NDF}$, and ADF in cows fed low RDS TMR was higher than those in cows fed high RDS TMR. Conversely, the starch digestibility was lower in cows fed low RDS TMR than in cows fed high RDS TMR.

There was no difference in the nitrogen intake between the dietary treatments (Table 5). The $\mathrm{N}$ secretion in milk, fecal $\mathrm{N}$ excretion and retained $\mathrm{N}$ were not affected by dietary treatments. However, significant difference in urinary $\mathrm{N}$ excretion $(\mathrm{p}=0.02)$ was observed. The urinary $\mathrm{N}$ excretion was higher for cows fed low RDS TMR than for cows fed high RDS TMR. However, as a proportion of $\mathrm{N}$ intake, the milk $\mathrm{N}$ secretion and $\mathrm{N}$ retention were not influenced by the dietary treatments, but significant difference in fecal $\mathrm{N}$ excretion $(\mathrm{p}=0.01)$ and urinary $\mathrm{N}$ excretion

Table 4. Effects of dietary ruminally degradable starch levels on total-tract apparent digestibility in dairy cows

\begin{tabular}{lcccc}
\hline Item & Low RDS $^{\text {1) }}$ & High RDS & SEM & p-value \\
\hline DM & 66.65 & 65.79 & 0.82 & 0.46 \\
OM & 73.69 & 71.43 & 0.81 & 0.09 \\
CP & 72.21 & 70.05 & 0.61 & 0.01 \\
NDF & 38.54 & 35.81 & 0.67 & 0.04 \\
ADF & 26.27 & 23.73 & 0.66 & 0.04 \\
Starch & 97.10 & 98.50 & 0.42 & 0.05 \\
\hline
\end{tabular}

SEM, standard error of the mean; $\mathrm{DM}$, dry matter; $\mathrm{OM}$, organic matter; $\mathrm{CP}$, crude protein; NDF, neutral detergent fiber; ADF, acid detergent fiber.

1) RDS, ruminally degradable starch $62.3 \%$ and $72.1 \%$ for the low and high RDS treatments, respectively, as determined by in situ incubations.
Table 5. The effects of dietary ruminally degradable starch levels on nitrogen utilization in dairy cows

\begin{tabular}{|c|c|c|c|c|}
\hline Item & Low $\operatorname{RDS}^{1)}$ & High RDS & SEM & $p$-value \\
\hline \multicolumn{5}{|l|}{$\mathrm{N}$ balance } \\
\hline$N$ intake (g/d) & 662.3 & 645.9 & 8.6 & 0.19 \\
\hline \multicolumn{5}{|l|}{ Milk N²) } \\
\hline$g / d$ & 155.4 & 147.8 & 4.64 & 0.13 \\
\hline$\%$ of $\mathrm{N}$ intake & 23.46 & 22.90 & 0.75 & 0.52 \\
\hline \multicolumn{5}{|l|}{ Fecal N excretion } \\
\hline$g / d$ & 184.2 & 193.7 & 5.74 & 0.12 \\
\hline$\%$ of $\mathrm{N}$ intake & 27.79 & 29.95 & 0.61 & 0.01 \\
\hline \multicolumn{5}{|l|}{ Urinary N excretion } \\
\hline $\mathrm{g} / \mathrm{d}$ & 240.0 & 201.3 & 11.27 & 0.02 \\
\hline$\%$ of $\mathrm{N}$ intake & 36.29 & 31.16 & 1.72 & 0.03 \\
\hline \multicolumn{5}{|l|}{$\mathrm{N}$ retention } \\
\hline $\mathrm{g} / \mathrm{d}$ & 82.7 & 103.1 & 11.82 & 0.26 \\
\hline$\%$ of $\mathrm{N}$ intake & 12.46 & 15.99 & 1.76 & 0.19 \\
\hline \multicolumn{5}{|l|}{ Urinary excretion (mM/d) } \\
\hline Allantoin & 536.69 & 534.04 & 26.78 & 0.92 \\
\hline Uric acid & 71.39 & 71.54 & 4.00 & 0.99 \\
\hline Total PD & 608.13 & 605.58 & 27.39 & 0.94 \\
\hline Microbial N supply) $(\mathrm{g} / \mathrm{d})$ & 474.52 & 472.35 & 23.00 & 0.93 \\
\hline \multicolumn{5}{|c|}{$\begin{array}{l}\text { SEM, standard error of the mean; PD, purine derivatives (allantoin and uric acid). } \\
\text { 1) RDS, ruminally degradable starch } 62.3 \% \text { and } 72.1 \% \text { for the low and high RDS treat- } \\
\text { ments, respectively, as determined by in situ incubations. } \\
{ }^{2)} \text { Milk } N=\text { milk protein yield/6.38. }\end{array}$} \\
\hline
\end{tabular}

$(\mathrm{p}=0.03)$ was detected. As a proportion of $\mathrm{N}$ intake, fecal $\mathrm{N}$ excretion was lower, and the urinary $\mathrm{N}$ excretion was higher for cows fed low RDS TMR than for cows fed high RDS TMR. There was no difference in the urinary allantoin, uric acid, total $\mathrm{PD}$ and calculated intestinal flow of microbial $\mathrm{N}$ between dietary treatments.

\section{DISCUSSION}

The observation that DMI was not affected by the dietary treatments is consistent with previously reported results. Krause et al [15] showed that increasing the level of ruminally fermentable starch did not affected DMI when refined cornstarch replaced starch from dry cracked shelled corn up to $57.0 \%$ of the total dietary starch with around 30\% dietary starch. Miyaji et al [16] compared diets containing steam-flaked brown rice or SFC at approximately $30 \%$ of dietary DM, but found that DMI was not affected by treatments. However, some studies have shown that DMI decreased when cows were fed more ruminally degradable starch sources [17,18]. Oba and Allen [18] suggested that these DMI depressions might be explained by a higher propionate production in the rumen when cows were fed the starch source with greater ruminal degradation. Propionate has greater hypophagic effects than acetate [19]. Therefore, inconsistent effects of ruminal starch digestibility on feed intake might imply that a threshold exists for propionate to affect DMI. In this study, we speculated that the propionate production in the rumen when 
cows were fed high RDS TMR might not reach the threshold of inhibiting DMI. In this study, milk yield was not affected by the dietary treatments, which can be attributed to the similarity between treatments for DMI. Miyaji et al [16] reported starch digestibility increased in the rumen by replacing SFC with steamflaked brown rice in low starch diets (19.4\% to $21.9 \%$ of DM), and milk yield had no difference between the two diets. Similarly, Oba and Allen [18] showed that high-moisture corn as a substitute of ground corn had equivalent milk yield. The concentrations of milk protein, fat and lactose were not influenced by dietary RDS levels, the result is consistent with some previous report $[18,20]$. Cow fed high RDS TMR had lower MUN concentrations than cows fed low RDS TMR, suggesting a more efficient $\mathrm{N}$ utilization with high RDS diet. Dhiman et al [21] and Burkholder et al [22] showed that the increased starch digestibility in the rumen by replacing dry ground corn with SFC in diets decreased MUN concentration for dairy cows.

The increased digestibility of starch due to the substitution of SFC for FGC could be caused by more ruminally degradable starch of SFC compared with those of FGC. The steam-flaking process improved the proportion of starch from grains digested in the rumen [23]. The digestibility of NDF and ADF were different from starch digestibility. The result is consistent with some previous reports [20,24]. More starch fermentation may depress fiber digestion by a reduced ruminal $\mathrm{pH}$ [25]. Hoover [26] suggested that starch was associated with decrease in ruminal fiber disappearance, and was independent of changes in ruminal $\mathrm{pH}$. Starch inhibited fiber digestion because its rapid fermentation stimulated certain strains of bacteria to restrain fiber hydrolysis [27], then decreased total-tract fiber digestion with increasing more ruminally degradable starch. The observation that the total tract apparent digestibility of CP decreased when cows were fed more ruminally degradable starch is consistent with previously reported results. Oliveira et al [28], who fed dairy cows a diet with different RDS levels, reported that the digestibility of CP was lower in high RDS diets than those of low RDS diets. Similarly, when cows were fed a diet with an increment of SFC substituted for FGC in diets the CP digestibility showed a quadratic response [29]. However, some studies have shown that the total tract apparent digestibility of $\mathrm{CP}$ was not affected by the ruminally degradable starch levels [20,30]. Blaxter and Martin [31] suggested that increased bacterial growth in the rumen or in the intestines led to more bacterial protein into the feces. In this study, cow fed high RDS TMR had higher fecal nitrogen excretion as a proportion of $\mathrm{N}$ intake than cows fed low RDS TMR, which could partly explain the lower total tract apparent digestibility of crude protein of cows fed high RDS TMR than low RDS TMR. The observation that total tract digestibility of DM was not affected by the dietary treatments is consistent with previously reported results $[32,33]$. Although several studies observed that the digestibility of DM increased when cows were fed more ruminally degradable starch $[3,20]$. The inconsistent effects of RDS levels on DM digestibility can be attributed to the difference in ingredient composition and digestibility of the different nutrient composition of the diets. In the current study, the increased digestibility of starch in the high RDS TMR may have offset any potential for the decreased digestibility of $\mathrm{CP}, \mathrm{NDF}$, and $\mathrm{ADF}$ to induce the total tract digestibility of $\mathrm{DM}$ depression.

The research showed that the $\mathrm{N}$ intake was not affected by the dietary treatments. This result was due to the DMI being similar between the dietary treatments and that the diets were isonitrogenous. However, the urinary $\mathrm{N}$ excretion and urinary $\mathrm{N}$ excretion as a proportion of $\mathrm{N}$ intake were less in cows fed high RDS TMR than in cows fed low RDS TMR, and the result was in agreement with the previous studies [22,34]. Ohtani et al [35] showed that supplying more fermentable starch in the diet could increase production of ruminal propionic acid which is a glucose precursor, and then reduce urinary $\mathrm{N}$ losses through reducing the amino acids (AA) used for gluconeogenesis. Additionally, the AAs used for gluconeogenesis increase when the dietary starch is low [36]. Nocek and Russell [37] suggested that the imbalance between $\mathrm{N}$ and energy availability in diets can promote utilization of AAs as an energy source which gives rise to a considerable absorption of ammonia through the ruminal wall. Therefore, The MUN and urinary N excretion were higher for cows fed low RDS TMR than for cows fed high RDS TMR, which was due to the imbalance between $\mathrm{N}$ and energy availability in the rumen. The milk $\mathrm{N}$ as a proportion of $\mathrm{N}$ intake was similar between the dietary treatments, this is consistent with the previous researches $[16,38]$. $\mathrm{N}$ retention as a proportion of $\mathrm{N}$ was similar between the dietary treatments. This agrees with a previous report [16] and contrasts with other previous reports $[20,34]$. The inconsistent effects of RDS levels on $\mathrm{N}$ retention as a proportion of $\mathrm{N}$ can be attributed to the differences of $\mathrm{N}$ intake and starch levels. Increasing ruminal availability of dietary starch increased the ruminal microbial $\mathrm{N}$ efficiency [3]. The high RDS diet might increase ruminal $\mathrm{N}$ use by supplying a more available starch for microbial protein production. However, no significant differences existed in the urinary PD excretions between the dietary treatments, and microbial $\mathrm{N}$ that passed to the small intestine was not significantly altered by the dietary treatments, the results were similar to previous report $[20,39]$. Beauchemin et al [39] suggested that more degradable starch decreased ruminal fibre digestion and offset the beneficial effects of the higher ruminal starch digestibility, resulting in a similar amount of OM fermented in the rumen. The OM fermented in the rumen is an important factor that contributes to the determination of the amount of microbial $\mathrm{N}$ that passes to the duodenum [40]. The results of the influence of RDS in the diet were not always consistent. For example, a review shows that more RDS in the diet rose microbial $\mathrm{N}$ supply in two studies and had no influence in five studies [41]. Therefore, inconsistent effects of ruminal starch digestibility on microbial $\mathrm{N}$ might imply 
that differences in the amount of feed intake, dietary sources of $\mathrm{N}$ and energy, solid and liquid rumen outflow rates contribute to asynchrony between $\mathrm{N}$ and energy availabilities in the rumen.

\section{CONCLUSION}

This study showed the levels of ruminally degradable starch with 62.3 and 72.1 (\% of total starch) did not influence DMI or yields of milk and milk components. The whole-tract apparent digestibility of NDF, ADF, and CP decreased, and that of starch increased for cows fed high RDS TMR compared with those fed low RDS TMR, with no effect on the whole-tract apparent digestibility of dry matter and organic matter. As a proportion of $\mathrm{N}$ intake, urinary $\mathrm{N}$ excretion was reduced, and fecal $\mathrm{N}$ excretion increased with the high RDS diet in place of low RDS diet. This study show that ruminally degradable starch levels can influence whole-tract nutrient digestibility and nitrogen balance in dairy cows fed low corn-based starch diets, with no influence on performance. Further studies are needed to determine the optimal RDS levels for avoiding the depression in digestibility of fiber and crude protein in low-starch diets.

\section{CONFLICT OF INTEREST}

We certify that there is no conflict of interest with any financial organization regarding the material discussed in the manuscript.

\section{ACKNOWLEDGMENTS}

This research was supported by grants from the China Agricultural Research System (Beijing, China; no. CARS-37).

\section{REFERENCES}

1.Godfray HCJ, Crute IR, Haddad L, et al. The future of the global food system. Philos Trans R Soc Lond 2010;365:2769-77.

2.Firkins J, Eastridge M, St-Pierre N, Noftsger S. Effects of grain variability and processing on starch utilization by lactating dairy cattle. J Anim Sci 2001;79:E218-E38.

3.Krause K, Combs D, Beauchemin K. Effects of forage particle size and grain fermentability in midlactation cows. I. Milk production and diet digestibility. J Dairy Sci 2002;85:1936-46.

4.Huntington GB. Hepatic urea synthesis and site and rate of urea removal from blood of beef steers fed alfalfa hay or a high concentrate diet. Can J Anim Sci 1989;69:215-23.

5.Ørskov E. The effect of processing on digestion and utilization of cereals by ruminants. Proc Nutr Soc 1976;35:245-52.

6.Reynolds CK, Sutton JD, Beever DE. Effects of feeding starch to dairy cattle on nutrient availability and production. In: Garnsworthy PC, Wiseman J, editors. Recent Advances in Animal Nutrition. Nottingham: Nottingham University Press; 1997. p. 105.

7.Allen MS. Effects of diet on short-term regulation of feed intake by lactating dairy cattle. J Dairy Sci 2000;83:1598-624.

8.MOA (Ministry of Agriculture, China). Feeding Standard of Dairy Cattle (NY/T 34-2004). Beijing, China: Ministry of Agriculture, China; 2004.

9.Yu P, Christensen D, McKinnon J. In situ rumen degradation kinetics of timothy and alfalfa as affected by cultivar and stage of maturity. Can J Anim Sci 2004;84:255-63.

10. AOAC. Official Methods of Analysis. 15th edn. Association of Official Analytical Chemists, Arlington, VA: AOAC International; 1990.

11. Van Soest Pv, Robertson J, Lewis B. Methods for dietary fiber, neutral detergent fiber, and nonstarch polysaccharides in relation to animal nutrition. J Dairy Sci 1991;74:3583-97.

12. Chen XB, Gomes M. Estimation of microbial protein supply to sheep and cattle based on urinary excretion of purine derivatives-an overview of the technical details. Rowett Research Institute, Aberdeen, UK: International Feed Resources Unit; 1992.

13. Valadares R, Broderick G, Valadares Filho S, Clayton M. Effect of replacing alfalfa silage with high moisture corn on ruminal protein synthesis estimated from excretion of total purine derivatives. J Dairy Sci 1999;82:2686-96.

14. SAS Institute Inc. SAS User’s Guide: Statistics. Version 9.2. SAS Inst. Inc., Cary, NC: SAS Institute Inc.; 2004.

15. Krause KM, Combs DK, Beauchemin KA. Effects of increasing levels of refined cornstarch in the diet of lactating dairy cows on performance and ruminal pH. J Dairy Sci 2003;86:1341-53.

16. Miyaji M, Matsuyama H, Hosoda K, Nonaka K. Milk production, nutrient digestibility and nitrogen balance in lactating cows fed total mixed ration silages containing steam-flaked brown rice as substitute for steam-flaked corn, and wet food by-products. Anim Sci J 2013;84:483-8.

17. Yang WZ, Beauchemin KA, Rode LM. Effects of barley grain processing on extent of digestion and milk production of lactating cows. J Dairy Sci 2000;83:554-68.

18. Oba M, Allen MS. Effects of corn grain conservation method on feeding behavior and productivity of lactating dairy cows at two dietary starch concentrations. J Dairy Sci 2003;86:174-83.

19. Sheperd A, Combs D. Long-term effects of acetate and propionate on voluntary feed intake by midlactation cows. J Dairy Sci 1998;81: 2240-50.

20. Miyaji M, Matsuyama H, Hosoda K. Effect of substituting brown rice for corn on lactation and digestion in dairy cows fed diets with a high proportion of grain. J Dairy Sci 2014;97:952-60.

21. Dhiman T, Zaman M, MacQueen I, Boman R. Influence of corn processing and frequency of feeding on cow performance. J Dairy Sci 2002;85:217-26.

22. Burkholder K, Guyton A, McKinney J, Knowlton K. The effect of steam flaked or dry ground corn and supplemental phytic acid on nitrogen partitioning in lactating cows and ammonia emission from manure. J Dairy Sci 2004;87:2546-53.

23. Huntington GB. Starch utilization by ruminants: from basics to the bunk. J Anim Sci 1997;75:852-67.

24. Yu P, Huber J, Santos F, Simas J, Theurer C. Effects of ground, steam- 
flaked, and steam-rolled corn grains on performance of lactating cows. J Dairy Sci 1998;81:777-83.

25. Sutton JD, Bines J, Morant S, Napper D, Givens D. A comparison of starchy and fibrous concentrates for milk production, energy utilization and hay intake by Friesian cows. J Agric Sci 1987;109: 375-86.

26. Hoover W. Chemical factors involved in ruminal fiber digestion. J Dairy Sci 1986;69:2755-66.

27. Smith W, Yu I, Hungate R. Factors affecting cellulolysis by Ruminococcus albus. J Bacteriol 1973;114:729-37.

28. Oliveira J, Huber J, Ben-Ghedalia D, et al. Influence of sorghum grain processing on performance of lactating dairy cows. J Dairy Sci 1993;76:575-81.

29. Zhong RZ, Li JG, Gao YX, Tan ZL, Ren GP. Effects of substitution of different levels of steam-flaked corn for finely ground corn on lactation and digestion in early lactation dairy cows. J Dairy Sci 2008;91:3931-7.

30. Hatew B, Podesta SC, Van Laar H, et al. Effects of dietary starch content and rate of fermentation on methane production in lactating dairy cows. J Dairy Sci 2015;98:486-99.

31. Blaxter K, Martin A. The utilization of protein as a source of energy in fattening sheep. Br J Nutr 1962;16:397-407.

32. Zhou X, Zhang Y, Zhao M, et al. Effect of dietary energy source and level on nutrient digestibility, rumen microbial protein synthesis, and milk performance in lactating dairy cows. J Dairy Sci 2015;98: 7209-17.

33. Bernard J, Chandler P, West J, et al. Effect of supplemental l-lysine$\mathrm{HCl}$ and corn source on rumen fermentation and amino acid flow to the small intestine. J Dairy Sci 2004;87:399-405.
34. Miyaji M, Matsuyama H, Hosoda K, Nonaka K. Effect of replacing corn with brown rice grain in a total mixed ration silage on milk production, ruminal fermentation and nitrogen balance in lactating dairy cows. Anim Sci J 2012;83:585-93.

35. Ohtani F, Takusari N, Ueno T. Influence of readily fermentable carbohydrate supplementation to the diet on nitrogen excretion in lactating cows. Nihon Chikusan Gakkaiho 2001;72:239-46.

36. Lemosquet S, Rigout S, Bach A, Rulquin H, Blum J. Glucose metabolism in lactating cows in response to isoenergetic infusions of propionic acid or duodenal glucose. J Dairy Sci 2004;87:1767-77.

37. Nocek JE, Russell JB. Protein and energy as an integrated system. Relationship of ruminal protein and carbohydrate availability to microbial synthesis and milk production. J Dairy Sci 1988;71:2070107.

38. Chibisa G, Gorka P, Penner G, Berthiaume R, Mutsvangwa T. Effects of partial replacement of dietary starch from barley or corn with lactose on ruminal function, short-chain fatty acid absorption, nitrogen utilization, and production performance of dairy cows. J Dairy Sci 2015;98:2627-40.

39. Beauchemin KA, Yang WZ, Rode LM. Effects of grain source and enzyme additive on site and extent of nutrient digestion in dairy cows. J Dairy Sci 1999;82:378-90.

40. Clark JH, Klusmeyer TH, Cameron MR. Microbial protein synthesis and flows of nitrogen fractions to the duodenum of dairy cows. J Dairy Sci 1992;75:2304-23.

41. Cabrita ARJ, Dewhurst RJ, Abreu JMF, Fonseca AJM. Evaluation of the effects of synchronising the availability of $\mathrm{N}$ and energy on rumen function and production responses of dairy cows-a review. Anim Res 2006;55:1-24. 